\title{
Prof. Hiro Narabayashi
}

\section{In Memoriam}

\section{Chihiro Ohye ${ }^{\mathrm{a}}$ Harald Fodstad $^{\mathrm{b}}$}

aHidaka Hospital, Functional and Gamma Knife Surgery Center, Gunma, Japan and bDivision of Neurosurgery, New York Methodist Hospital-Cornell University, New York, N.Y., USA

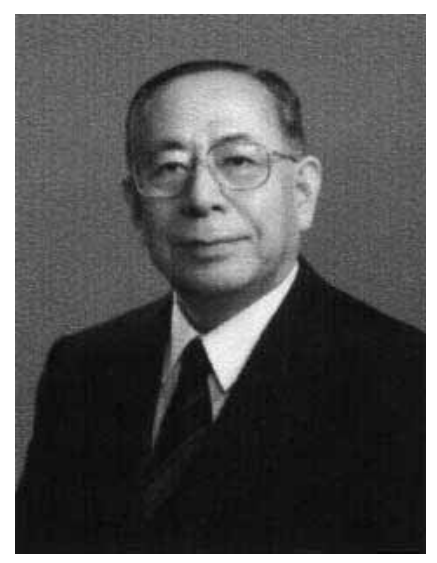

The sad news of the sudden death of our teacher, friend and pioneer of stereotactic surgery, Professor Hirotaro Narabayashi, came as a great shock. Hiro was his nickname and he was loved by everyone who had the privilege to know him. He was so full of life and new ideas, always active and busy moving around, talking, arguing and explaining. It is difficult to accept and believe that such a vibrant man is no longer among us.

Dr. Narabayashi was born in Kobe, Japan on September 4, 1922, and grew up in Nagasaki. He graduated from the University of Tokyo School of Medicine just after World War II and joined Professor Y. Uchimura's Department of Psychiatry. He had a particular interest in extrapyramidal disease inspired by Alfons Jakob's German textbook, which he read as a medical student just before the end of the war [1]. At that time patients with Parkinson's disease were cared for in the Psychiatry Department, but certainly no effective treatment existed. Incidentally, Professor T. Ogawa had just returned from Ranson's laboratory in America with a drawing of Horsley and Clarke's stereotaxic apparatus for use in animal experiments. When he suggested the possibility to use it in man, young Narabayashi was immediately inspired and took action to realize the idea, but, unfortunately, this was a time of post-war chaos with Tokyo almost completely destroyed by bombardment. It was not easy to find anyone who could make such an instrument, but Narabayashi

\begin{tabular}{ll}
\hline KARGER & ( 2002 S. Karger AG, Basel \\
Fax +4161306 1234 & 1011-6125/01/0764-0125\$18.50/0 \\
$\begin{array}{l}\text { E-Mail karger@karger.ch } \\
\text { www.karger.com }\end{array}$ & $\begin{array}{l}\text { Accessible online at: } \\
\text { www.karger.com/journals/sfn }\end{array}$
\end{tabular}

Dr. C. Ohye, Hidaka Hospital

Functional and Gamma Knife Surgery Center 886 Nakao-machi, Gunma 370-0001 (Japan) Tel. +8127362 6201, Fax +81273628901 E-Mail stereohye@dan.wind.ne.jp 
finally located a small factory that was willing to cooperate with him. Thus, his first stereotactic instrument was made in 1949 and reported in Kyoto in 1950. This model was not used in man, and a revised model 2 (1951) and model 3 (1953) followed. When Spiegel and Wycis reported the first human stereotactic operation in 1947, Japan was occupied by the United States. Communication with other countries was difficult and foreign medical journals were unavailable. Therefore, Narabayashi was unaware of the work of others when he developed stereotaxy in post-war Japan.

Narabayashi's first application of his own instrument was a pallidotomy in an athetoid child in 1951. The most exciting moment came on June 4, 1952, when the first pallidotomy on Parkinson's disease was successfully accomplished. Immediately after injection of a small amount of oil wax (procaine-oil and bee's wax), the patient's tremor and rigidity were almost completely abolished. The patient, Narabayashi and Professor Uchimura were all surprised, pleased and excited. It was, in fact, the third operation on this patient. A few months earlier he had been operated on the caudate nucleus and putamen without any change in involuntary movements. The patient was kind enough to accept the third operation without any guarantee of success. Seeing this wonderful result, Professor Uchimura advised Narabayashi that it contained an entirely new reality and said that 'this I know shall be the work, the theme for your whole life'. Narabayashi followed his Professor's advice and devoted the rest of his professional life to stereotaxy.

For several years after the war, the Japanese people went through severe hardships with shortage of most basics, including food, clothing and housing, but everybody worked hard, and medical doctors were no exception. Meanwhile, Neurosurgery Departments were established in the University Hospitals one by one and stereotactic surgery was readily embraced because it represented a new idea and method. Narabayashi stood as a central leading person in this process. In 1957, at a time when the Japanese medical system was still in disarray, he founded his own private institute for human stereoencephalotomy in Tokyo. In Narabayashi's opinion, opening his own clinic was the best and perhaps only way he could develop the new operative technique. There he continued his stereotactic work, parallel to serving as Associate Professor of Psychiatry and later as full Professor of Neurology at Juntendo University.

The Neurological Clinic soon became a Mecca for stereotaxy and attracted many young and bright doctors who joined to learn, collaborate and enjoy the open and free discussions with Narabayashi. Also in 1957, he went abroad for the first time to attend the First International Meeting of Neurology and Neurosurgery in Brussels. There he had the opportunity to exchange ideas and meet with the other pioneers of stereotactic surgery. His work on stereotactic pallidotomy was appreciated by many, including Spiegel and Wycis. After several visits to interna-

$\overline{126} \overline{\text { Stereotact Funct Neurosurg }} \quad \overline{\text { Dedication }}$ 
tional conferences, Narabayashi had a strong feeling that cooperation with basic scientists is inevitable to achieve a true scientific approach to stereotactic surgery. Fortunately, his Neurological Clinic was supported by members of the Brain Research Institute at Tokyo University (Professor Tokizane was the Chairman), and physiological analysis of rigidity, tremor and thalamocortical evoked potentials were conducted by the young staff members, including one of us (C.O.). From that time on, Narabayashi went abroad more than 100 times, running from one country to the other. His foreign friends used to joke that 'Hiro has his own private jetplane'.

By the late 1950's almost every Neurosurgical Department in Japan had a stereotactic section. The Japanese Society of Stereotactic Surgery was founded in 1963 and the first meeting was held in Kyoto. The Society now meets annually and has about 500 members. Narabayashi is the only person to be elected twice as the President of the Society. He also served as Convenor of the 6th Meeting of World Society of Stereotactic and Functional Neurosurgery in Tokyo in 1973 and served two terms as President of the World Society from 1973 to 1981 . He was awarded the Spiegel and Wycis Medal in 1989 for his unique contributions to the development of Stereotactic and Functional Surgery. Furthermore, he was elected Honorary Member of many foreign medical societies, including the American and French Societies of Neurology.

The introduction of $L$-Dopa in the late 1960's was a temporary setback for stereotactic surgery. Whereas many stereotactic sections in Japan were forced to close, the Neurological Clinic continued operating as usual. The total number of stereotactic procedures performed by Narabayashi amounts to 4,000. Around this time, Dr. Ohye introduced microrecording technique from France. Since then, microrecording has become a routine adjuvant method for precise targeting of the thalamus and basal ganglia. This again has led to a better understanding of the functional organization of the human thalamus. Narabayashi also collaborated with biochemists, and their research on catecholamine metabolism in relation to basic mechanisms of Parkinson's disease resulted in the production of an adrenergic system-activating drug. Narabayashi's voluminous bibliography was cited when he officially retired in 1988 [2]. During more than 40 years the internationally renowned Neurological Clinic was visited by neuroscientists from almost all parts of the universe. Every visitor wrote a note in his guestbooks, which we hope will be preserved for future generations of stereotactic neurosurgeons.

For five decades Narabayashi was an important player in the world of stereotaxy, and usually one step ahead of the rest of us. However, his last year was tragic. In April 2000, he suffered a left retinal hemorrhage and because of a previous right-sided bleed, he lost most of his central vision. He bitterly complained that he could no longer read papers or think properly and had to stop operating and close 
his operating room. Worse to come, his wife, who suffered from renal failure, died in October 2000. Five months later, mentally depressed and physically exhausted, our Hiro passed away. The world has lost a great man and scientist and we have lost a warm-hearted, compassionate and devoted friend.

\section{References}

1 Jakob A: Die Extrapyramidalen Krankheiten. Berlin, Springer Verlag, 1923.

2 Developments in Research: The Works of Professor Hirotaro Narabayashi and His Associates. Tokyo, Department of Neurology, Juntendo University School of Medicine, 1988. 